\title{
Individual Characteristics of Entrepreneurs in Transition Countries. The Albanian Case
}

\section{Summary}

The transition process in Albania, as in other ex-communist countries, stopped the enterprise development. The increasing number of small and medium enterprises is the most promising consequence of the transition process.

Several researches in western countries have demonstrated that entrepreneurship involves objective and subjective factors and is interrelated with environmental objective factors and individual subjective ones.

Our research examines clear characteristics of the businesses' analysis, the performance of the entrepreneurs themselves (their background and personal characteristics), their motivation to start a business and the perceptions of the different characteristics and the aspects of the businesses they run.

\section{Definition of Entrepreneurship and Entrepreneurs}

Storey (1994) argues that there is no uniformly acceptable definition of small firms due to a variety of factors, including: industry and sector influence on size; yardstick used; and subjective and conflicting statistical data on small and new firms. Bolton Committee (1971) tried to correlate the economic and statistical features and linked those with the industry factor while regarded small firms as:

- with relatively small share of market;

- managed by owners or part-owners in a personalised way;

- independent.

* Prof. dr, Faculty of Economics, University of Tirana, Albania.

** MBA, Ministry of Finance, Albania.

*** MA, Faculty of Economics, University of Tirana, Albania. 
Wynarczyk et al. (1993) tried to identify characteristics of small firms, other than size, arguing that small and large firms are as fundamentally different from each other as a caterpillar is from a butterfly. He notes that small firms are risky because:

- are price-taker;

- have limited customer base;

- owners have diverse objectives.

Considering that "the entrepreneur is the person who engages in an enterprise", is clear that the definition of the entrepreneur is derived from the one of the enterprise. The entrepreneur is the one who engages in the activity of establishing and running a company. More specifically the entrepreneur is the one who has an idea on a business/product/ service and applies that idea.

Practice and scientific research has shown that entrepreneurs have something that others don't have. The typical entrepreneur's profile has changed over time. Research has shown important individual characteristics to the entrepreneur's success. The conclusion is that entrepreneurship depends on the entrepreneur's individual nature.

Other researches identify other important characteristics of entrepreneurs. Shapiro (1979) identifies the trust in their own skills and abilities, the constant need to be the lord of their own fate and the faith that they can be promoters of change. McClelland (1961) emphasizes their need for success, their lack of collaboration or social motivation. Filley (1978) emphasize their lack of interest for details, lack of interest for the hierarchy and/or organisational structure and standard managerial activities as main characteristics of entrepreneurs. Collins and Moore (1989) show the need of entrepreneurs to dominate while Hisrich and Peter (1993) emphasize the internal locus of control, need for independence and need for success. Kuehl and Lambing (1994) cite 6 main characteristics for a successful entrepreneurs: (1) internal locus of control, (2) high energy, (3) need for success, (4) self-confidence, (5) ability to "seize the moment" and (6) no compromises.

Several other studies besides focusing on the individual characteristics of entrepreneurs also emphasize the entrepreneur's background such as gender, age, civil status, educational level, entrepreneurial culture and other important success factors.

Through this research the authors will try to identify these characteristics and identify the backgrounds of the Albanian entrepreneurs.

\section{Empirical Analysis}

With the main goal of identifying the main characteristics of the Albanian entrepreneurs the authors interviewed entrepreneurs in selected small companies. The interviews were based in a structured questionnaire. The analysis of the survey is also compared with similar results in other countries. This material identifies the main tendencies in medium and small companies and presents some performances of Albanian entrepreneurs that have not been considered previously.

The results of the research will be focused in the following main issues:

1) characteristics of entrepreneurial behaviour,

2) characteristics of entrepreneurial background, 
3) personal characteristics of the entrepreneurs,

4) entrepreneurial motivation, and

5) perceptions and opinions of entrepreneurs regarding business development aspects.

\subsection{Characteristics of entrepreneurial behaviour}

The main economic activity of both cases is retail (Table 1). These results are based in real case examples of Albania (2008). The majority of the SME's in Albania are in the retail sector.

The concentration in the companies being analysed is very high. Exactly $75 \%$ of companies are working in only one economic sector. $28 \%$ are working with different activities but similar to each other and only $15 \%$ are working in different sectors. This implies that small and medium enterprises should differentiate their product/service to survive or advance in the market. They do this by focusing in one specific business/ industry, by doing what they do best.

The size of the enterprises expressed by number of employees in Albania in 2008, shows that the successful enterprises in Albania are established, improved and employ less (Table 2). In Eastern Europe, about 35\% of companies have more than 10 employees.

In Albania enterprises with less than 10 employees are about $86 \%$ of the total number of enterprises. The facts show that in Albania the initial survival phase is very difficult and fewer companies make it through the first 5 initial years. The companies that have surpassed the initial phase have a stable position in the market and employ more than the same businesses but in the initial phase.

Table 1. Firm distribution by economic activity, 2008

\begin{tabular}{|l|c|}
\hline \multicolumn{1}{|c|}{ Economic Activity } & $\mathbf{2 0 0 8}(\%)$ \\
\hline Production & 8,3 \\
\hline Agriculture & 1,6 \\
\hline Transport & 6,5 \\
\hline Construction & 11,2 \\
\hline Retail & 42,3 \\
\hline Financial Services & 2,8 \\
\hline Personal Services & 12,7 \\
\hline Business Services & 6,2 \\
\hline Hotel/Restaurant/Catering & 8,4 \\
\hline
\end{tabular}

Table 2. Enterprises by size, 2008

\begin{tabular}{|l|c|}
\hline \multicolumn{1}{|c|}{ Number of employees } & $\mathbf{2 0 0 8}(\mathbf{\% )}$ \\
\hline $1-10$ employees & 86,50 \\
\hline $11-20$ employees & 9,60 \\
\hline $21-50$ employees & 3,40 \\
\hline $51-80$ employees & 0,50 \\
\hline Total & 100,00 \\
\hline
\end{tabular}


The fact that the businesses in Albania survive more and increase the number of employees is related with the type of employees that they employ. Only in $19 \%$ of the cases they employ only family members, in $42 \%$ of the cases they employ both family and non-family members, while $39 \%$ of the enterprises employ non-family members. This could be an indication that the enterprises in Albania are attracting new human resources and skilled labour that sometimes is very difficult to be found in the family members.

The life of the companies is based on the following data (Table 3). About $80 \%$ of the enterprises have surpassed the critical initial phase of the 5 years. The data also show that the exponential tendency of the newly stabilised businesses, typical for transition countries, is decreasing. In Albania there are about 5000 new businesses on average every year during the period 1993-2003. This tendency has decreased in Eastern Europe considering the fact that the entry barriers now are higher, while in Albania the barriers are lower and now are needed only 7 days to open a business compared to 39 days that it used to be before.

The market where the majority of these companies operate is still limited and is explained by the following data (Table 4). With the development and increase of the companies is also developed the market. The data show that the number of companies that serve to the national market is higher in Albania than in Eastern Europe. There is a small rate of companies who also serve the international market. These companies are focused on niche products. From this can be noticed that Albanian entrepreneurs are not competitive and even less than the Eastern European ones.

There are about $74 \%$ of companies in Albania who consider their position as moderate and about $4 \%$ as weak. This figure can be considered as low and demonstrates for a strong position among Albanian SME's. This data is contradictory with the fact that only $34 \%$ consider their competition below moderate. The market competition can be considered as a strong barrier to SME development.

Table 3. Entrepreneurial life, 2008

\begin{tabular}{|l|c|}
\hline \multicolumn{1}{|c|}{ Years of activity } & $\mathbf{2 0 0 8}(\mathbf{\%})$ \\
\hline $0-5$ years & 18,50 \\
\hline $6-10$ years & 43,00 \\
\hline $10-15$ years & 38,50 \\
\hline Total & 100,00 \\
\hline
\end{tabular}

Table 4. Market where enterprises operate, 2008

\begin{tabular}{|l|c|}
\hline \multicolumn{1}{|c|}{ Market } & 2008 (\%) \\
\hline Local & 31 \\
\hline Regional & 17 \\
\hline National & 45 \\
\hline International & 7 \\
\hline Total & 100 \\
\hline
\end{tabular}


Table 5. Perceptions of entrepreneurs about the market competition, 2008

\begin{tabular}{|l|c|}
\hline \multicolumn{1}{|c|}{ Market competition } & 2008 (\%) \\
\hline Low & 8 \\
\hline Moderate & 26 \\
\hline High & 49 \\
\hline Very high & 17 \\
\hline Total & 100 \\
\hline
\end{tabular}

Table 6. Perceptions of entrepreneurs about the market position, 2008

\begin{tabular}{|l|c|}
\hline \multicolumn{1}{|c|}{ Market position } & 2008 (\%) \\
\hline Weak & 4 \\
\hline Moderate & 74 \\
\hline Strong & 22 \\
\hline Total & 100 \\
\hline
\end{tabular}

\subsection{Entrepreneurial Background}

Research shows that the gender of entrepreneurs in Albania is congruent with the majority of entrepreneurs all over the world. The data show that business is managed by men. In Albania this ratio is higher where $85 \%$ are male and about $15 \%$ female.

The data show that entrepreneurs are middle aged (Table 7). According to the latest data more than $70 \%$ of entrepreneurs in Albania are over 40 . The same trend is also noticed in Eastern Europe where this ratio is about $52 \%$. This is mainly related with the fact this age group used to be working previously in the state enterprises which were privatised, but also the bank-client relationship where banks prefer support stable, experienced entrepreneurs rather than young and inexperienced ones.

Educational level of the majority of entrepreneurs in Albania is relatively low. This could also be a good indicator considering the fact that the majority of the most successful entrepreneurs have had educational problems. In Albania 55\% of the owners of SME's

Table 7. Entrepreneur's age 2008

\begin{tabular}{|l|c|}
\hline \multicolumn{1}{|c|}{ Age } & 2008 (\%) \\
\hline$<$ than 25 years & 3 \\
\hline $25-30$ years & 8 \\
\hline $30-35$ years & 6 \\
\hline $35-40$ years & 12 \\
\hline $40-45$ years & 27 \\
\hline $45-50$ years & 25 \\
\hline$>$ se 50 years & 19 \\
\hline Total & 100 \\
\hline
\end{tabular}


have a second level diploma, while about $41 \%$ have a university degree. When the business is not managed by the owner but by a manager/administrator about $38 \%$ of them have a second level diploma and about $58 \%$ have a university degree. This shows that the entrepreneurs that consider the university degree important are increasing. In the developed countries the tendency is for the entrepreneurs to have a master degree. The fact that the educational level of managers/owners is higher and the increasing tendency among entrepreneurs is also related with the fact that entrepreneurs were middle aged.

The majority of the entrepreneurs in Albania have been previously employed from different private and public companies (58\% compared to 90\% in Eastern Europe). 4\% of the interviewed have previously worked in family businesses and only $6 \%$ have been previously unemployed. There is a strong relationship between the previous employment and the existing business. $45 \%$ of the interviewed entrepreneurs operate in the same industry/field where they did before becoming entrepreneurs, $41 \%$ are quite in the same business and $14 \%$ are in different businesses. This means that about $90 \%$ of the entrepreneurs have experience about the business/industry where they do operate

\subsection{Personal entrepreneurial characteristics}

Entrepreneurs where asked to rank 5 characteristics that characterize them more, or the 3 and 5 characteristics that they believe are the most important for the successful entrepreneurs (Table 8).

It is clear that entrepreneurs in Albania consider "expertise" and "independence" as most important characteristics for themselves and entrepreneurs as well. In Albania this is not the case. The entrepreneurs distinguish between their characteristics and the characteristics needed in order to be a successful entrepreneur. One of the main characteristics emerged in Albania is the expertise.

Table 8. Entrepreneurs' perceptions, 2008

\begin{tabular}{|l|c|l|c|}
\hline \multicolumn{1}{|c|}{ Image of themselves } & $\%$ & \multicolumn{1}{c|}{ Entrepreneurs' image } & $\%$ \\
\hline Expertise & 40,3 & Ambition & 51,9 \\
\hline Independence & 40,3 & Expertise & 50,0 \\
\hline Care & 38,9 & Persistence & 35,2 \\
\hline Communic. & 34,7 & Communic. & 33,3 \\
\hline Ambition & 33,3 & Care & 29,6 \\
\hline Flexibility & 27,8 & Determination & 29,6 \\
\hline Persistence & 27,8 & Creativity & 27,8 \\
\hline Creativity & 26,4 & Self Confidence & 27,8 \\
\hline Determination & 25,0 & Initiation & 25,9 \\
\hline Quietness & 22,2 & Quietness & 22,2 \\
\hline Sociability & 20,8 & Independence & 20,4 \\
\hline Initiation & 20,8 & Goal oriented & 20,4 \\
\hline Practical & 20,8 & Risk adversity & 18,5 \\
\hline
\end{tabular}

Note: Entrepreneurs were asked to select 5 characteristics, that add to $100 \%$. 
Table 9. The most important characteristic for the entrepreneurial success, 2008

\begin{tabular}{|l|c|}
\hline \multicolumn{1}{|c|}{ Entrepreneurs Characteristics } & 2008 (\%) \\
\hline "Business intuition" & 53 \\
\hline Education & 22 \\
\hline Communication & 16 \\
\hline Political relationships & 1 \\
\hline Others & 8 \\
\hline Total & 100 \\
\hline
\end{tabular}

When entrepreneurs were asked to identify only one characteristic as the most important one contributing to success, the following answers were received (Table 9).

$53 \%$ of entrepreneurs have identified "business intuition" as the main precondition for the entrepreneurial success and only $22 \%$ identified "education", meaning business knowledge (expertise) as the vital characteristic.

The leadership style used by entrepreneurs is autocratic. Exactly $71 \%$ of Albanian entrepreneurs take decision without consulting with their dependents. $61 \%$ of these autocratic leaders take decisions using only the most valuable information while 39\% consider the information provided by their dependents. $43 \%$ of the consultative leaders present the problem and consider the ideas and suggestions of the team before the decision making process. Only $9 \%$ of entrepreneurs use the participative leadership style and solve problems in collaboration with the group.

The autocratic leadership style is typical for small and medium sized companies because at the initial stage of the business the entrepreneurs tend to have full control of the business. In the case of a dynamic environment and an increasing number of employees, the entrepreneur should change and adapt the leadership style.

\subsection{Motivation to start a business}

The motivation to start a business is shown by the following indicators (Table 10). The main reason to start a business in Albania is "need for independence". The high ranking for this reason can be explained by the fact that the previous communist society limited free enterprises. Surprisingly "financial profits" does not rank high. This could have been the case at the beginning of the 90 -ies. This is also the case for the majority of the entrepreneurs all over the world. Entrepreneurs are often guided by money.

The second main most important reason for Albanian entrepreneurs was "need for independence". The third main reason is "need to apply a business idea".

Considering that the private sector is stabilising, it is clear that these motives are becoming important and "financial profits" does not rank high. Even though entrepreneurs are profit oriented they are also motivated by other incentives. 
Table 10. Motivation to start a business, 2008

\begin{tabular}{|l|c|c|}
\hline \multicolumn{1}{|c|}{ Motives to start a business } & \% & Rank \\
\hline Need for independence & 26 & 1 \\
\hline Financial profit & 10 & 4 \\
\hline Increased cash flow & 5 & 6 \\
\hline Need to apply a business idea & 20 & 3 \\
\hline Need for change & 1 & 9 \\
\hline Family tradition & 4 & 7,5 \\
\hline Need for achievement and success & 7 & 5 \\
\hline A lot of motives & 23 & 2 \\
\hline Other & 4 & 7,5 \\
\hline Total & 100 & $/$ \\
\hline
\end{tabular}

\subsection{Entrepreneurs' opinion about their business and specific business development aspects}

The research tries also to understand entrepreneur's perceptions and opinions regarding success, future plans, most favourite and hated aspect of work etc.

When entrepreneurs were asked to which factor they attribute success they unanimously answered (87\%) that quality of products and services, quality of business development and customer satisfaction were key to success. Only a relatively small part of the entrepreneurs (11\%) consider "contacts and informal networks" vital to achieve success and even a smaller percentage $(2 \%)$ consider "fate and coincidence" as key to success.

'Entrepreneurs in Albania think that the primary objective of every business is to survive (94\%). Only $2 \%$ of the interviewed think that their primary goal is "increased profits" and a small part (4\%) think that their goal is society's wellbeing.

The most attractive aspect of business development for Albanian entrepreneurs corresponds to work (Table 11).

From a research on barriers to SME's (Tabaku, 2005) the most important problem that SME's in Albania face are taxes $(24,2 \%)$ and second non-legal competition $(21,8 \%)$.

Table 11. Most attractive business's aspect, 2008

\begin{tabular}{|l|c|c|}
\hline \multicolumn{1}{|c|}{ Business's aspects } & \% & Rank \\
\hline Profits & 12 & 3 \\
\hline Independence & 31 & 2 \\
\hline Relationships & 11 & 1 \\
\hline Dynamic work & 36 & $/$ \\
\hline Travel & 0 & 5 \\
\hline Others & 10 & $/$ \\
\hline Total & 100 & 4 \\
\hline
\end{tabular}


Today Albanian entrepreneurs face different challenges (Table 12). It can be noticed that the main challenges still rank high but the difference is smoothed and there is an increased importance to the infrastructure problems.

When asked about business and management functions entrepreneurs gave interesting answers (Table 13). About 30 of them dealt regularly with sales. It can be concluded that the vital aspect of businesses in Albania, is sales. As in the rest of the world if you don't sell you cannot survive. The main question here is if sales could be the most important business aspect that they dealt with? The authors believe that the sales are really important considering the fact that Albania is a country in transition and there is a clear lack of liquidities.

The managerial function to which Albanian entrepreneurs give less importance is strangely enough "planning".

Albanian entrepreneurs think that the hygiene motivation factors motivate their employees. $68 \%$ think that the main incentive is" money", $13 \%$ relate motivation to "type of work", $7 \%$ think that the main incentive is "profit sharing", $5 \%$ think that the main incentive is "good relationship with superior" and 5\% are motivated by "carrier opportunities". Only $1 \%$ of entrepreneurs think that they are motivated by internal factors.

Table 12. Main business barriers, 2005 and 2008

\begin{tabular}{|l|c|l|c|}
\hline \multicolumn{2}{|c|}{ Business aspect } & \multicolumn{2}{c|}{2008} \\
\hline Taxes & $\%$ & \multicolumn{1}{c|}{ Business aspect } & 15,9 \\
\hline Non legal payments & 24,2 & Taxes & 9,2 \\
\hline Non legal competition & 11,2 & Non legal payments & 19,5 \\
\hline Microcredit access & 21,8 & Non legal competition & 10,8 \\
\hline Problems with inputs & 13,9 & Microcredit access & 8,1 \\
\hline Problems with physical infrastructure & 6 & Problems with inputs & 15,9 \\
\hline Burochracy & 14,1 & Burochracy & 11,7 \\
\hline Inspection & 1 & Inspection & 9 \\
\hline
\end{tabular}

Note: Entrepreneurs emphasized more than one barrier, the total is more than $100 \%$.

Table 13. Business and managerial functions, 2008

\begin{tabular}{|l|c|l|c|}
\hline \multicolumn{1}{|c|}{ Business functions } & $\%$ & \multicolumn{1}{c|}{ Managerial functions } & $\%$ \\
\hline Sales & 24.3 & Leadership and motivation & 24.3 \\
\hline Supplying & 23 & Organisation & 24.3 \\
\hline Finance & 21.6 & Control & 13.5 \\
\cline { 1 - 2 } Production & 20.3 & Planning & 10.8 \\
\cline { 1 - 2 } Marketing & 18.9 & & \\
\cline { 1 - 2 } Research and development & 10.8 & & \\
\cline { 1 - 2 } Administrative work & 10.8 & & \\
\cline { 1 - 3 } Accounting & 5.4 & & \\
\cline { 1 - 3 } & & & \\
\end{tabular}

Note: Entrepreneurs emphasized more than one element, the total is more than $100 \%$. 
Table 14. Future plans, 2008

\begin{tabular}{|l|c|}
\hline \multicolumn{1}{|c|}{ Plans } & $\%$ \\
\hline Improving competitive advantages and market position & 31 \\
\hline New markets & 15 \\
\hline Expanding business & 13 \\
\hline Increasing number of employees & 3 \\
\hline Maintaining existing level & 18 \\
\hline No other plans & 1 \\
\hline Others & 19 \\
\hline Total & 100 \\
\hline
\end{tabular}

When asked about future forecasts regarding sales, number of employees and their salaries entrepreneurs were optimistic. On average they forecasted that their sales and number of employees would be increased by $50 \%$.

They were also optimistic about future plans (Table 14). Mori than $60 \%$ of them had plans to expand in the future.

\section{Conclusions}

Even though Albanian entrepreneurs have similar characteristics to those of the western entrepreneurs there are still big differences mainly related to the development stage of the country. Several changes need to take place not only in the environment, which is a structural change, but one more important and difficult to take place the one is culture. The structural changes are needed to also reduce the barriers faced by SME's. The reality is such that even though have passed about 18 years of transition businesses have liquidity, tax and access to credit problems.

At a different transition stage, when the structural problems will be smoothed, is needed another research to investigate the Albanian entrepreneurial profile. The entrepreneurs that will survive to this transition will be those who will serve as agents of change for the economy.

This research is just a start, the entrepreneurial profile is very wide and still needs a lot of attention in terms of research.

\section{References}

Bahtijarević-Šiber F., Management ljudskih potencijala, Golden Marketing, Zagreb 1996.

Filley A.C., Aldag R.J., Characteristics and Measurement of an Organizational Typology, The Academy of Management Journal, Vol. 21, No. 4, 1978.

Kuehl Ch.R., Lambing P., (1994), Small Business, 3rd ed., Dryden Press, Fort Worth 1994.

Larson K.D., Wild J.J., Chiapetta B., Fundamental Accounting Principles, 15th ed., McGraw-Hill, Boston 1999.

Longenecker J.G., Moore C.W., Petty J.W., Small Business Management, 10th ed., South-Western, Cincinnati (OH) 1997. 
McClelland D.C., The Achieving Society, D. Van Nostrand Company, Inc., Princeton 1961.

Robert D.H., Szirmai P., Developing a Market Oriented Economy: A Hungarian Perspective, Entrepreneurship \& Regional Development, Volume 5, Issue 1, 1993.

Shapiro P., Miyao T., Smith T.R., Environmental Quality and Economic Development, "Environment and Planning" A 11(10) 1147 - 1156, 1979.

Storey D.J., Understanding the Small Business Sector, International Thomson Business Press, London 1994.

Tabaku J., Financing Alternatives Influencing SMEs Behaviour, MA Thesis, Durham University, Durham 2005.

Zimmerer T.W., Scarborough N.M., Essentials of Entrepreneurship and Small Business Management, 3rd ed., Prentice Hall, Upper Saddle River (NJ) 2002.

\section{Charakterystyka przedsiębiorców w krajach w procesie transformacji. Przykład Albanii}

\section{Streszczenie}

Procesy transformacji zachodzqce w Albanii, jako jednym z bytych europejskich krajów komunistycznych, spowodowały rozwój przedsiębiorstw. Można zatem stwierdzić, iż rosnaca liczba małych i średnich firm jest jednq z bardziej obiecujacych konsekwencji procesu transformacji. Zachodni badacze problemu wskazuja, że rozwój przedsiębiorczości wymaga spetnienia kilku czynników obiektywnych, wynikajacych z uwarunkowań otoczenia oraz czynników subiektywnych, zależnych od indywidualnego przedsiębiorcy. $W$ artykule przedstawiono ocenę przedsiębiorców albańskich oraz ich motywację do uruchomienia i prowadzenia działalności gospodarczej. 